\title{
Risk of ectopic pregnancy associated with gynecological history, past con- traceptive use, and smoking habit
}

\author{
Bastaman Basuki
}

\begin{abstract}
Abstrak
Makalah ini merupakan salah satu bagian analisis penelitian kasus-kontrol populasi risiko kehamilan ektopik terganggu (KET) yang berkaitan dengan pemakaian kontrasepsi di masa lalu, riwayat obstetrik-ginekologik, dan merokok di 11 kota di Indonesia pada tahun 1989/1990. Kasus adalah KET yang dikonfirmasikan berdasarkan pemeriksaan histopatologik, dan seorang kontrol wanita hamil untuk setiap kasus KET yang dipadankan menurut daerah kerja penelitian serta interval umur lima tahunan wanita yang masih menikah. Wawancara dilakukan untuk memperoleh data mengenai metode kontrasepsi di masa lalu, riwayat obstetrik-ginekologik, serta karakteristik demografik. Kasus KET dan kontrol yang pada saat perkiraan konsepsi terjadi masih menggunakan kontrasepsi, tidak diikutsertakan dalam analisis ini, sehingga diperoleh 456 KET dan 596 kontrol. Faktor risiko obstetrik-ginekologik yang mempertinggi risiko KET ialah KET terdahulu (risiko relatif [RR] suaian $=16,84 ; 95 \%$ interval kepercayaan [CI]: 2,14-132,50), inflamasi pelvis $(P I D)$, riwayat induksi haid, dan abortus spontan. Kontrasepsi masa lalu (alat kontrasepsi dalam rahim [AKDR], suntikan, metode alamiah) mencegah $K E T$, yaitu $R R$ suaian metode alamiah $=0,18 ; 95 \%$ CI: 0,05-0,54, metode suntikan $R R$ suaian $=0.51 ; 95 \% \mathrm{CI}$ : 0,37-0,72 relatif terhadap mereka yang tidak pernah memakai kontrasepsi yang berkenaan. Relatif terhadap yang tidak pernah memakai AKDR, AKDR di masa lalu selama 13-36 bulan menurunkan risiko KET (RR suaian 0,47; 95\% Cl 0,24-0,93), dan 36-202 bulan (RR suaian 0,58; 95\% CI0,36-0,94). Relatifterhadap yang tidak pernah merokok, perokok cenderung berisiko tinggi KET (tes kecenderungan suaian $p<0,001$ ). Risiko KET mencolok di antara mereka yang merokok selama 36-360 bulan ( $R R$ suaian = 3,20; 95\% CI: 1,30-7,83). Dapat disimpulkan bahwa abortus spontan, induksi haid, PID, dan merokok mempertinggi risiko KET. Sedangkan pemakaian kontrasepsi dimasa lalu memperkecil risiko KET.
\end{abstract}

\begin{abstract}
This analysis is a part of a population-based case-control study in 11 cities in Indonesia in 1989/1990 to assess risk of ectopic pregnancy $(E P)$ associated with past contraceptive use, obstetrical-gynecological history, and smoking habit. Cases were EP histopathologically confirmed and one pregnant control for each case was matched by catchment area and five-year age interval of married women. Personal interviews were conducted in collecting information regarding past contraceptive use, obstetrical-gynecological history, and demographic characteristics. Cases and pregnant controls that at the estimated date of conception were still using any contraceptive methods were excluded from this analysis, 456 cases and 506 pregnant controls were included. The obstetrical-gynecological risk factors which increased the risk of EP were previous EP (adjusted RR $=16.84 ; 95 \%$ CI: 2.14-132.50), PID (pelvic inflammatory disease), history of induced abortion and spontaneous abortion. Past contraceptive use (IUD, injectable, natural method) prevented $E P$, i.e. past natural method, natural method (adjusted $R R=0.18 ; 95 \% \mathrm{CI}: 0.05-0.54$ ), past injectable method (adjusted $R R=0.51$; 95\% CI: 0.37-0.72) relative to never used of respective contraceptives, and relative to never used IUD, past IUD use for 13-36 months (adjusted RR 0.47; 95\% CI 0.24-0.93), and 36-202 months (adjusted RR 0.58; 95\% CI 0.36-0.94). Relative to non smokers, longer duration of smoking tends to increase risk of EP (adjusted test for trend $p<0.001$ ). The risk was most pronounced in smokers for $36-360$ months (adjusted $R R=3.20 ; 95 \%$ CI: 1.30-7.83). In conclusion, PID, miscarriage, induced abortion, and smoking habit increase risk of $E P$, however past contraceptive use prevented $E P$.
\end{abstract}

Keywords: ectopic pregnancy, contraception, gynecological, smoking habit

Results of previous studies indicate that, among fertile women, gynecological infection, history of obstetrical operation, and contraceptive use may increase risk of ectopic pregnancy (EP). ${ }^{1,2}$ Association of past IUD

Department of Community Medicine, University of Indonesia Faculty of Medicine, Jakarta, Indonesia (intrauterine device) use with the increase risk of EP have been reported, suggesting that women who use an IUD may sustain tubal damage which exerts a residual influence on the risk of EP after the device is removed. ${ }^{3-5}$ However, the current public health significance of prior study findings has been questioned. Subsequent analyses and later study reports showed that IUD might be protecting women from acquiring 
EP. ${ }^{1}$ Contraception with an IUD is now recommended primarily to married women in mutually monogamous relationship, as these women are in general thought to be in lower risk of sexually transmitted disease. ${ }^{6}$

Past hormonal and other interval contraceptive methods seem to be lowering the risk of EP,,$^{1,2}$ and later studies reports indicated that smoking habits increase risk of EP. ${ }^{1-3,7,8}$

In addition, in Indonesia there are more than 20 million women who are contraceptive users, which were using IUDs, pills, injectables, implants, and condoms. They were at risk of EP related to the contraceptive methods.

Since EP is life threatening and no population-based study has been conducted in Indonesia, therefore it is beneficial to conduct an epidemiological study. This analysis are based on data on multi-center case-control study of married, gravid women (while still sexually active) in Indonesia in order to assess the risk of EP among women who are not currently using any contraception at the estimated date of conception

\section{Methods}

As part of the population-based case-control study which was conducted in 11 cities in Indonesia, namely in Medan, Padang, Palembang, Jakarta, Bandung, Semarang, Yogyakarta, Surabaya, Denpasar, Ujungpandang and Manado, that have teaching hospitals primarily serving defined catchment areas, during the period of 1 April 1989 to 31 August 1990 which referred to 2,222,000 eligible couples.

Cases were EP that were histologically confirmed by histopathologist by the presence of trophoblast, fetal, or chorionic villus tissue in a sample taken at surgery. The women also had to be married, 15 to 44 years of age at diagnosis, and to reside within one of defined catchment areas of the hospitals. Cases were identified by treating physicians and referred to a specially trained nurse-midwife for interview. Interview was conducted in hospital within the third or fourth day of hospitalization. During the period, 560 eligible cases were identified and all completed the interviews.

The control group consisted of married women who lived within the catchment area that was served by the participating hospitals. The control group was clinical- ly pregnant women of less than 20-week of pregnancy. The controls were matched to the cases by catchment area and five-year age interval. Each cases was matched by one pregnant control.

Controls were randomly selected from the catchment areas of participating hospitals in the following manner. For each area, subdistrict consisting of 40 to 60 neighborhood were identified, and neighborhoods were randomly selected from this list. Each neighborhood included from 20 to 40 eligible women. Eligibility was determined at four-month intervals through a door-to-door census. Potential controls were ordered by age group of five-year intervals (15-19, $20-24,25-29,30-34,35-39$, and 40-44 years) and catchment area. One pregnant control was randomly matched to each case. If a selected control was not available for interview after two return visits to her home, an alternative control was selected.

A nurse-midwife interviewed control women in their homes. Although the interviewers of cases and controls differed, the interviewers were similarly trained specifically for this study. A total of 560 pregnant controls were interviewed.

For cases and pregnant controls, information collected pertained to exposures and characteristics prior to the estimated date of conception of EP. Each women was asked to report her current method that is, method at conception for case and pregnant control, of birth control, length of time she had been continuously using that last method, the longest duration of using that method, and the total duration of use. Similar information was collected regarding use of every other birth control method that had previously been used. An additional information from women who ever used an IUD, the following information was asked: the last type of IUD used; the duration of the last IUD use; whether or not symptoms of pelvic inflammatory disease had occurred while using an IUD; and the reasons for discontinuation of the last IUD used, and whether at the estimated date of conception were still using any contraceptive methods.

Current users of any contraceptive methods at the estimated date of conception were defined as follows. IUD, pill, minipill, condom, vaginal jelly, or natural method current users were those who for one month or less before the estimated date of conception were still using contraceptive method; Injectable and implant methods were those who for three months or less before the estimated date of conception had injectable or implant contraceptive methods. 
Cases and pregnant controls that at the estimated date of conception were still using any contraceptive methods lower the risk of having pregnancy, ${ }^{9}$ therefore 104 cases and 54 pregnant controls were excluded. After exclusion, cases which met the criteria were 456, and 506 of pregnant controls.

A number of risk factors were examined as potential confounders and/or effect modifiers, including: cigarette smoking habit (never, former, current); study center, education (high = senior high school or above, middle = primary school or junior high school, lower=none or read only); age (15-19, 20-24, 25-29, $30-34,35-39,40-44$ years); history of PID (never or ever); history of spontaneous abortion (never or ever); history of induced abortion (never or ever); history of EP (never or ever); parity (2 or more, 1, none); history of a prior episode of IUD use (never or ever). PID was defined as a history of treatment for PID or symptoms of lower abdominal pain and fever.

Logistic regression analysis ${ }^{10}$ was used in order to control for the confounding effects of risk factors on the relationship between the risk factors and EP. A risk factor was considered to be a potential confounder if upon completing of the univariate test has a p-value $<0.25$ which will be considered as a candidate for the multivariate model along with all risk factors of known biological importance. ${ }^{19}$

Characteristics that fulfilled this definition as confounders are included by the method of maximum likelihood. Ninety-five percent confidence intervals were based on the standard error of coefficient estimates. Calculation using unconditional logistic methods, and based on candidate of potential risk factors, for the simplicity, the final model was constructed by stepwise method using Egret software. ${ }^{12}$

Since the cases and controls were most likely to be representative sample for the catchment areas, therefore the relative risk (RR) is closely appropriated by the odds ratio, ${ }^{11}$ the term relative risk (RR) was used instead of odds ratio (OR) throughout the text.

This study was approved by the Ethical Committee of the National Family Planning Coordinating Board of Indonesia.

\section{Results}

Cases and pregnant controls were similarly distributed with respect to study center $(\mathrm{p}=0.995)$ and age group $(p=0.882)$. In term of education levels, a moderate difference was found between cases and controls $(p=0.089)$. Pregnant controls more likely to have higher education level compared to cases (Table 1).

Table 1. Some characteristics of subjects

\begin{tabular}{|c|c|c|c|c|c|}
\hline \multirow[t]{2}{*}{$\sqrt{2}+x^{2}$} & \multicolumn{2}{|c|}{$\begin{array}{l}\text { Ectopic } \\
(\mathrm{N}=456)\end{array}$} & \multicolumn{2}{|c|}{$\begin{array}{l}\text { Pregnant control } \\
\qquad(N=506)\end{array}$} & \multirow[t]{2}{*}{ p } \\
\hline & $\mathrm{n}$ & $\%$ & $\mathrm{n}$ & $\%$ & \\
\hline Center & & & & & 0.995 \\
\hline Medan & 53 & 11.6 & 58 & 11.5 & \\
\hline Padang & 25 & 5.5 & 27 & 5.3 & \\
\hline Palembang & 29 & 6.4 & 24 & 4.7 & \\
\hline Jakarta & 107 & 23.5 & 114 & 22.5 & \\
\hline Bandung & 53 & 11.6 & 66 & 13.0 & \\
\hline Semarang & 24 & 5.3 & 25 & 4.9 & \\
\hline Yogyakarta & 30 & 6.6 & 33 & 6.5 & \\
\hline Surabaya & 41 & 9.0 & 45 & 8.9 & \\
\hline Denpasar & 41 & 9.0 & 49 & 9.7 & \\
\hline Ujungpandang & 31 & 6.8 & 38 & 7.5 & \\
\hline Manado & 22 & 4.8 & 27 & 5.3 & \\
\hline Age group & & & & & 0.882 \\
\hline 15-19 years & 12 & 2.6 & 13 & 2.6 & \\
\hline 20-24 years & 86 & 18.9 & 90 & 17.8 & \\
\hline $25-29$ years & 180 & 39.5 & 195 & 38.5 & \\
\hline 30-34 years & 120 & 26.3 & 137 & 27.1 & \\
\hline $35-39$ years & 52 & 11.4 & 64 & 12.6 & \\
\hline 40-44 years & 6 & 1.3 & 7 & 1.4 & \\
\hline Education & & & & & 0.089 \\
\hline High school or above & 128 & 28.1 & 166 & 32.8 & \\
\hline $\begin{array}{l}\text { Primary or junior high } \\
\text { school }\end{array}$ & 235 & 51.5 & 261 & 51.6 & \\
\hline Illiterate or read only & 93 & 20.4 & 79 & 15.6 & \\
\hline
\end{tabular}

Results from univariate analysis (Table 2) shows that those who had more parity had an increased risk of EP compared to those who never had livebirth. In general, it seemed that past contraceptive use lower the risk of EP. Those who ever used IUDs in a period longer than 12 months seemed to be more protected against EP compared to those who never used IUD. Number of past IUD use episodes also lower the risk of EP. History of past use of injectable, pills, and natural methods seemed to be lowering the risk of EP.

The risk of implant and minipill users can not be evaluated because there was no such subjects in the study.

In term of obstetrical and gynecological conditions, those who ever had miscarriage, induced abortion, tubal operation, and previous EP increased the risk of EP. There is no evidence that history of mola, appen- 
Table 2. Parity, past contraceptive uses and risk of ectopic pregnancy

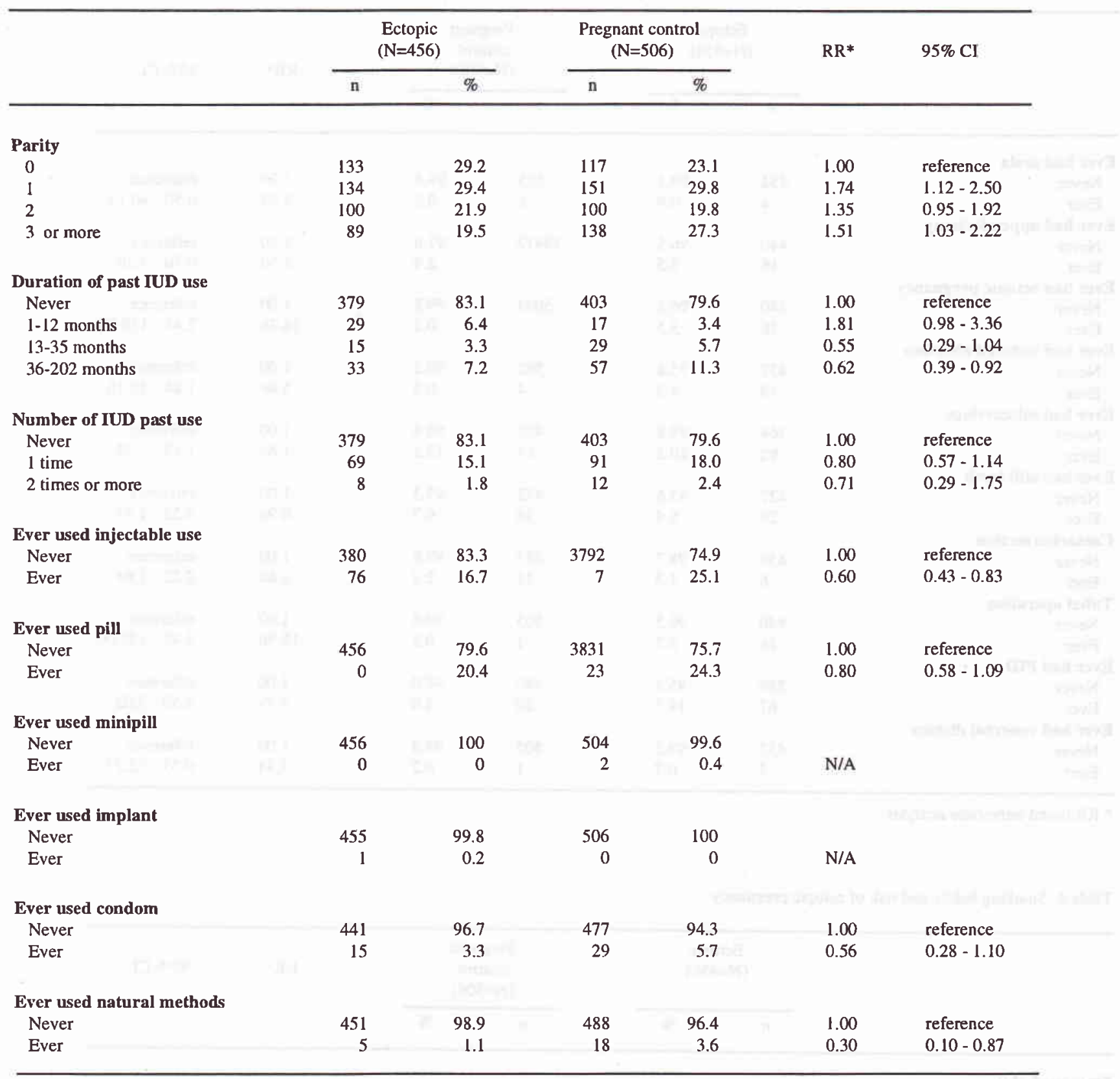

* Relative risk based on univariate analysis N/A not applicable

dectomy, and caesarian operation increased the risk of EP. Past incidence of PID increased the risk of EP. On the other hand, the data did not prove that past incidence of VD increase the risk of EP (Table 3 ).

Univariate analysis showed that current or past cigarette smoking, more number of cigarette consump- tion daily increased the risk of EP. In term of length of smoking period, those who smoke for 36 to 360 months had an increase of EP, but there is no evidence that those who smoke for 1-12 months or 13-35 months increased the risk of EP compared to non-smokers (Table 4). 
Table 3. Obstetrical and gynecological and risk of ectopic pregnancy

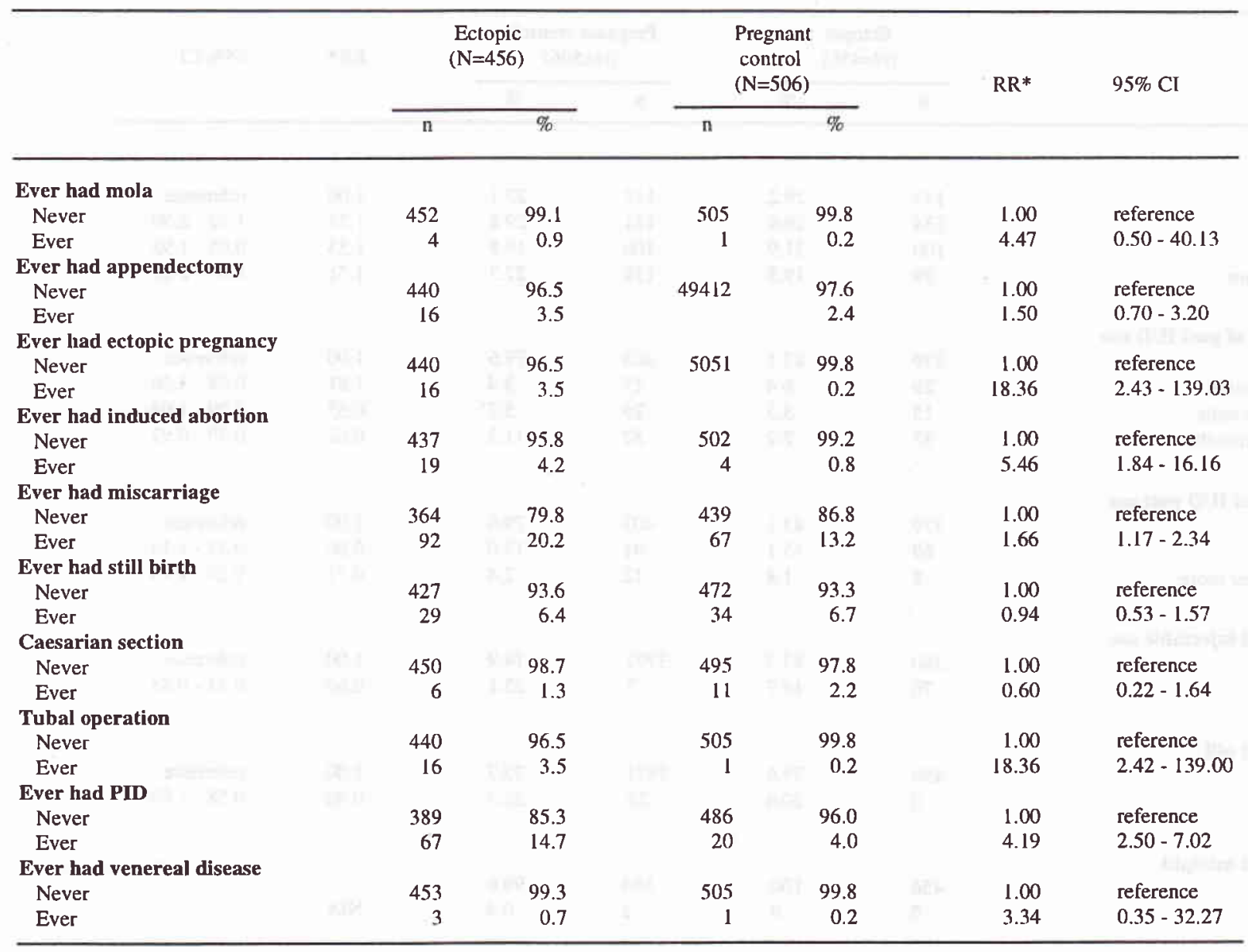

* RR based univariate analysis

Table 4. Smoking habits and risk of ectopic pregnancy

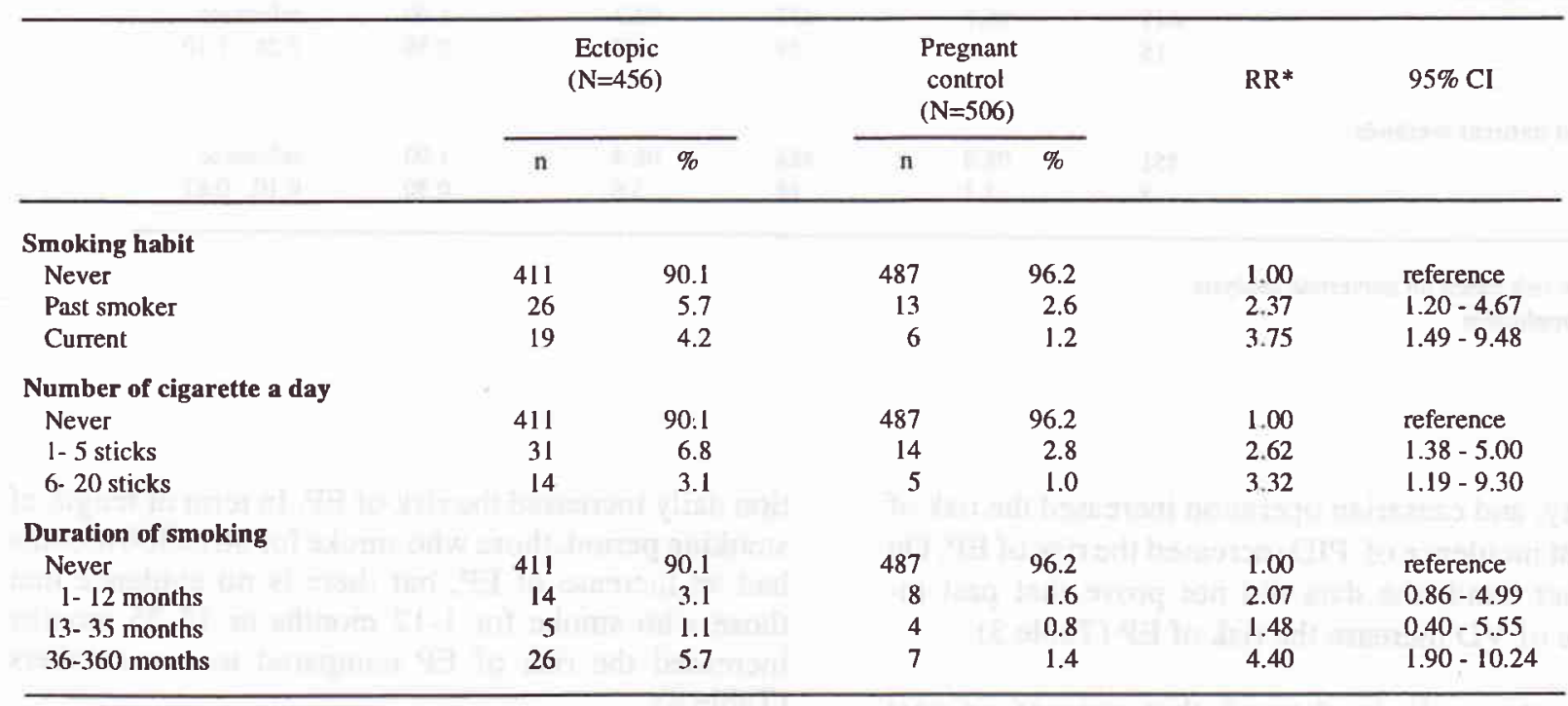

* Relative risk based on univariate analysis 
The final model as shown on Table 5 revealed that there were relationships between history of contraceptive methods (past IUD use, and past injectable use, past natural), obstetrical history (previous EP, induced abortion, and miscarriage), PID, and duration of smoking habits.

The most potential obstetrical-gynecological risk factor which increased the risk of EP was previous EP (adjusted RR $=16.84 ; 95 \%$ CI: 2.14-2126). History of induced abortion, PID, and history of spontaneous abortion followed.

History of past contraceptive methods (past IUD use, past injectable use, past natural method) lowered the risk of EP. The most potential past contraceptive method which protected the risk of EP are past natural method (adjusted RR $=0.18 ; 95 \%$ CI: $0.05-0.54$ ), followed by past injectable method (adjusted $R R=$ $0.51 ; 95 \%$ CI: $0.37-0.72$ ).
Relative to non IUD users, past IUD use for 1-12 months moderately increased the risk of EP (adjusted $\mathrm{RR}=1.65 ; 95 \% \mathrm{CI}: 0.84-3.22 ; \mathrm{p}=0.145$ ), however longer duration of IUD in the past protected against EP. Those who ever used IUD for 13-36 months had $53 \%$ lower risk of EP ( $R R=0.47 ; 95 \% \mathrm{CI}: 0.24-0.93$ ), and among who used IUD for 36-202 months had 42\% lower risk of $\mathrm{EP}(\mathrm{RR}=0.58 ; 95 \% \mathrm{CI}: 0.36-0.94)$ relative to non IUD subjects. In general, longer duration of past IUD use protected the risk of EP (adjusted test for trend $\mathrm{p}=0.015$ )

In term of duration of cigarette smoking habits, there is a trend that longer duration of smoking cigarette trend to increase the risk of EP (adjusted test for trend $\mathrm{p}<0.001$ ). Relative to non smokers, smoking habits for 1-12 months increases the risk of EP 2.7 times (adjusted RR $=2.76 ; 95 \%$ CI: 1.09-6.97), smoking habits for 36-360 months for 3.2 times (adjusted RR $=3.20 ; 95 \%$ CI: $1.30-7.83$ ). However, our data does not prove increased risk of EP for those who smoke for 13-35 months.

Table 5. Relationship between past contraceptive use, history obstetrical-gynecological, and smoking habits and risk of ectopic pregnancy

\begin{tabular}{|c|c|c|c|c|c|c|}
\hline & \multicolumn{2}{|c|}{$\begin{array}{c}\text { Ectopic } \\
(\mathrm{N}=456)\end{array}$} & \multicolumn{2}{|c|}{$\begin{array}{l}\text { Pregnant } \\
\text { control } \\
(\mathrm{N}=506)\end{array}$} & \multirow[t]{2}{*}{$\mathrm{RR}^{*}$} & \multirow[t]{2}{*}{$95 \% \mathrm{CI}$} \\
\hline & $\mathrm{n}$ & $\%$ & $\mathrm{n}$ & $\%$ & & \\
\hline \multicolumn{7}{|l|}{ Past IUD use } \\
\hline Never & 379 & 83.1 & 403 & 79.6 & 1.00 & reference \\
\hline $1-12$ months & 29 & 6.4 & 17 & 3.4 & 1.65 & $0.84-3.22$ \\
\hline 13-35 months & 15 & 3.3 & 29 & 5.7 & 0.47 & $0.24-0.93$ \\
\hline 36-202 months & 33 & 7.2 & 57 & 11.3 & 0.58 & $0.36-0.94$ \\
\hline \multicolumn{7}{|c|}{ Ever used injectable } \\
\hline Never & 380 & 83.3 & 379 & 74.9 & 1.00 & reference \\
\hline Ever & 93 & 16.7 & 127 & 25.1 & 0.51 & $0.37-0.72$ \\
\hline \multicolumn{7}{|c|}{ Ever used natural method } \\
\hline Never & 451 & 98.9 & 488 & 96.4 & 1.00 & reference \\
\hline Ever & 5 & 1.1 & 18 & 3.6 & 0.18 & $0.05-0.54$ \\
\hline \multicolumn{7}{|c|}{ Ever had ectopic pregnancy } \\
\hline Never & 440 & 96.5 & 505 & 99.8 & 1.00 & reference \\
\hline Ever & 16 & 3.5 & 1 & 0.2 & 16.84 & $2.14-132.50$ \\
\hline \multicolumn{7}{|c|}{ Ever had induced abortion } \\
\hline Never & 437 & 95.8 & 502 & 99.2 & 1.00 & reference \\
\hline Ever & 19 & 4.2 & 4 & 0.8 & 6.70 & $2.11-21.26$ \\
\hline \multicolumn{7}{|c|}{ Ever had miscarriage } \\
\hline Never & 364 & 79.8 & 439 & 86.8 & 1.00 & reference \\
\hline Ever & 92 & 20.2 & 67 & 13.2 & 1.63 & $1.29-2.35$ \\
\hline \multicolumn{7}{|c|}{ Ever had pelvic inflammatory disease } \\
\hline Never & 389 & 85.3 & 486 & 96.0 & 1.00 & reference \\
\hline Ever & 67 & 14.7 & 20 & 4.0 & 4.47 & $2.57-7.76$ \\
\hline \multicolumn{7}{|c|}{ Duration of smoking habit } \\
\hline Never & 411 & 90.1 & 487 & 96.2 & 1.00 & reference \\
\hline $1-12$ months & 14 & 3.1 & 8 & 1.6 & 2.76 & $1.09-6.97$ \\
\hline $13-35$ months & 5 & 1.1 & 4 & 0.9 & 0.81 & $0.17-3.91$ \\
\hline $36-360$ months & 26 & 5.7 & 7 & 1.4 & 3.20 & $1.30-7.83$ \\
\hline
\end{tabular}

* Adjusted for each other risk factors in this table 


\section{DISCUSSION}

There are several limitations, which must be considered in the interpretation of the findings. Firstly, case ascertainment, although based on a defined population, may be incomplete, as some women may have received medical care for their EP at a private hospital which was not participating in our study. However, although there are private hospitals operating within the study areas, the large majority of EPs are treated at the teaching hospitals from which our cases were identified. In addition, we have no data regarding the proportion of selected controls that were not interviewed.

Different individuals interviewed cases and controls. However, all interviewers have been similarly trained in the use of the data collection instrument.

We have no data on the aspect of IUD and the other contraceptive methods use that might have allowed us to more specifically examine risk factors associated with the last timing of these contraceptive methods used.

In spite of these limitations, the restriction of our study population to married, gravid women made our results more directly applicable than those of prior studies. Although we do have some evidence that controls were representative of the general population, as $22.1 \%$ of the total controls interviewed (including those who were excluded from these analysis) reported current use of an IUD, in which similar to overall proportion of IUD use $(22.2 \%)$ among Indonesia women in the area in which this study was conducted (personal communication, Indonesian National Family Coordinating Board). In addition, pregnant controls were selected randomly from random subset of neighborhood within the same catchment area as that of cases.

The final model suggested that past IUD, injectable, and natural contraceptive use may provide a degree of protection against EP relative to never having used any contraceptive method. After the discontinuation of these contraceptive methods would be expected to reduce the risk of EP.

The final model shows that natural methods (coitus interruptus and other traditional methods such as traditional herbs) are the most protecting contraceptive methods against EP. Coitus interruptus is the method most likely to prevent EP due to less probability of having an infection along with ejaculated sperm. Therefore, natural contraceptive methods are promis- ing methods to prevent EP. However, only a small number of our subjects practiced traditional methods. Among cases only $1.1 \%$ (5/456), and 3.6\% (18/506) among pregnant controls.

Those who ever used IUD for 1-12 months has 58\% moderate in increase risk of EP relative to never had an IUD ( $p=0.145)$, while for longer period of past IUD use reduce the risk of developing EP relative to those who never had any IUD. A longer duration of past IUD use protecting women of developing EP. Those who ever used IUD for 13-35 months had 52\% decrease, and for past IUD users for 36-202 months $42 \%$ decrease of risk to develop EP relative to never had past IUD use. This finding is similar with the results of multinational WHO (World Health Organization) study in 1978-1980 that past IUD use prevented EP.'

Women who ever reported PID was subsequently 4.5 fold increase risk of EP relative to those who never had PID. Others ${ }^{13,14}$ have noted that risk of symptomatic, diagnosed PID in IUD users is greatest shortly after insertion of IUD. This condition might be the reason, which increase risk of EP among those who had IUD for a short period. Our data, which show pelvic inflammatory disease increase the risk of E.P, is similar to others. $1,2,13,14$

The final model also shows that previous EP is the most prominent risk factor $(R R=16.84)$. This finding is consistent with previous population-based studies. ${ }^{1,13}$ These findings are not surprising because one would expect a woman with a damaged tubal structure which caused a previous EP to be more prone to develop a subsequent $\mathrm{EP}$ either in the contra lateral tube or, if conservative surgery were performed, in the repaired tube.

Some studies in developed countries found that previous induced abortion had little relation to EP. $1,15,16$ Other studies found that previous abortion did increase risk of EP. ${ }^{2,17}$ In Indonesia, a country where induced abortion is illegal, therefore induced abortion was performed illegally and might be by non-professional medical personnel with low quality of care. This elevated risk of EP among the subjects of $2.4 \%$ (23/962) who ever had previous abortion.

In addition, our data on smoking habit is similar with previous studies that indicated elevated risk of EP associated with cigarette smoking. ${ }^{1,5,18}$ Even though those who smoked for 13-35 months did not significantly have an increased risk of EP relative to non- 
smokers, but the final model indicates that in general smoking increases risk of EP (adjusted test for trend $\mathrm{p}$ $=0.003$ ). Cigarette smoking has been shown to reduce humoral and cellular immunity, and this impaired immunity may predispose smokers to pelvic infection, thus indirectly increasing the risk of EP. ${ }^{8,19}$

In conclusion, the final model revealed that past contraception (IUD, injectable, natural) use protected women against EP. Longer duration of IUD use also decreased the risk of EP. As previous studies noted, our data shows that PID, previous EP, and previous induced abortion as well as spontaneous abortion and smoking habit increased risk of EP. It is recommended to have a better quality and legal medical program for those who need medical services to overcome miscarriage and induced abortion problem, and finally a community program is needed on PID, as well as on smoking prevention among women.

\section{Acknowledgment}

The author thanks Dr. Olav Meirik (Special Program of Research, Development and Research Training in Human Reproduction, World Health Organization) and Dr. Sujana Jatiputera (School of Public Health University of Indonesia) for technical assistance in the preparation on the study. Special thanks are extended to Dr. Mary Anne Rossing (Fred Hutchinson Cancer Research Center, Seattle USA) for data verification and transformation of the study. Special thanks to colleagues in 11 centers in Indonesia for their high dedication in participating the study. And lastly to Dr. Abdul Bari Saifuddin to review earlier drafts of this manuscript that improved the final product.

\section{REFERENCES}

1. World Health Organization. Task force on intrauterine devices for fertility regulation. Clin Reprod Fertil 1986; 3:131-43.

2. Marchbank PA, Annegers JF, Coulam CB, Strathy JH, Kurland LT. Risk factors for ectopic pregnancy. A populationbased study. JAMA 1988;259: 1823-7.
3. Rossing MA, Daling JR, Voigt LF, Stergachis AS, Wang S-P, Grayston JT. Past use of an intrauterine device and risk of tubal pregnancy. Epidemiology 1993;4:245-51.

4. Thorbum JO, Philipson M, Lindblom B. Backgroungd factors of ectopic pregnancy II: Risk estimation by mean of logistic model. Eur J Obstet; 1986:333-40.

5. Daling JR, Weiss NS, Voigt LF, McKnight B. The intrauterine device and primary tubal infertility. $\mathrm{N}$ Engl J Med 1992; 326:203-4.

6. Anon. Diagnostic and therapeutic technology assessment. Intrauterine devices. JAMA 1989; 261:2127-30.

7. Hersey P, Prendergast D, Edwards A. Effect of cigarette smoking on the immunity system: follow-up studies in normal subjects after cessation of smoking. Med J Aust 1983;2:425-9.

8. Kalandidi A, Doulgerakis $M$, Tzonou A, et al. Induced abortions, contraceptive practices, and tobacco smoking as risk factors for ectopic pregnancy in Athens, Greece. $\mathrm{Br} J$ Obstet Gynecol 1991:98:207-13.

9. Weiss NS, Daling JR, Chow WH. Control definition in case-control studies of ectopic pregnancy. AJPH 1985 75:67-8.

10. Breslow NE, Day NE. Statistical Methods in Cancer Research Vol I. The analysis of case-control studies (IARC Sci Publ No.32). Lyon, France: Intemational Agency for Research on Cancer, 1980. p 93-115.

11. Hosmer DW, Lemeshow S. Applied logistic regression. New York. John Willey \& Sons. 1989. p 82-91

12. Statistics and epidemiology research Corporation. Egret: Reference manual. Seattle. 1990; p 134-61.

13. Farley TMM, Rosenberg MJ, Rowe PJ, Chen J-H, Meirik O. Intrauterine devices and pelvic inflammatory disease: an international perspective. Lancet 1992; 339: 785-8.

14. Lee NC, Rubin GL, Ory HW, Burkman RT. Type of intrauterine device and the risk of pelvic inflammatory disease. Obstet Gynecol 1983; 62:1-6.

15. Nordenskkjold F, Ahlgren M. Risk factor in ectopic pregnancy. Acta Obstet Gynecol Scan 1991; 575-9.

16. Daling JR, Chow WH, Weiss NS, Match BSR. Ectopic pregnancy in relation to previous induced abortion, JAMA $1985 ; 253: 1005-8$.

17. Panayotou PP, Kaskarelis DB, Mietinen OS et al. Induced abortion and ectopic pregnancy. Am J Obstet Gynecol 1972;114:507-10.

18. Levin AA, Schoenbaum SC, Stubblefield PG, et al. Ectopic pregnancy and prior induced abortion. Am J Public Health 1982;72:253-6.

19. Niles JH, Clark JFJ. Pathogenesis of tubal pregnancy. Am J Obstet Gynecol 1987;69:722-6. 